\title{
Potential of parents and hybrids experimental of the yellow melon
}

\author{
José Galdino Cavalcante Neto ${ }^{1}$ Karmita Thainá Correia Ferreira ${ }^{1}$ \\ Fernando Antonio Souza de Aragão ${ }^{2^{*}}$ (D) Rafaela Priscila Antônio ${ }^{3}$ (D) \\ Glauber Henrique de Sousa Nunes $^{4}$ (D)
}

\author{
${ }^{1}$ Programa de Pós-graduação em Fitotecnia, Universidade Federal Rural do Semi-árido (UFERSA), 59631-180, Mossoró, RN, Brasil. \\ ${ }^{2}$ Embrapa Agroindústria Tropical, Fortaleza, CE, Brasil. E-mail: fernando.aragao@embrapa.br. *Corresponding author. \\ ${ }^{3}$ Embrapa Semiárido, Petrolina, PE, Brasil. \\ ${ }^{4}$ Universidade Federal Rural do Semi-árido, Mossoró, RN, Brasil.
}

\begin{abstract}
Melon or muskmelon (Cucumis melo L.) is of considerable economic importance in Brazil. Nearly all the cultivars currently grown are hybrids. Heterosis has been used to advantage in the melon plant, and the use of uniform hybrids is one of the reasons for successful cultivation. The aim of the present study was to evaluate the agronomic potential of yellow melon lines and hybrids. An experiment was conducted in randomized blocks with three replications to evaluate 24 hybrids generated by crosses among three elite lines used as female parents (AF-01, AF-02, and AF-03) and eight lines used as male parents (LAM-01, LAM-02, LAM-03, LAM-04, LAM-05, LAM-06, LAM-07, and LAM-08). Yield and fruit quality traits were evaluated. Partial diallel analysis was carried out to estimate general combining ability and specific combining ability. Additive and non-additive effects were observed for the yield, mean fruit weight, and pulp thickness traits. The lines AF-02, LAM-02, and LAM-03 are the most promising as parents as they more frequently have favorable alleles. The most prominent hybrids in diallel analysis were AF-02 $x$ LAM-02, AF-02 $x$ LAM-03, AF-02 $\times$ LAM-04, and AF-03 $x$ LAM-06.

Key words: Cucumis melo L., combining ability, heterosis, diallel.
\end{abstract}

Potencial de parentais e híbridos experimentais de melão amarelo

RESUMO: O melão amarelo (Cucumis melo L.) é uma hortaliça de grande importância econômica. Atualmente as cultivares plantadas, em quase sua totalidade, são híbridos. A heterose tem sido explorada no meloeiro, sendo o emprego de híbridos uniformes uma das razóes do sucesso da cultura. O objetivo do presente trabalho foi avaliar o potencial agronômico de linhagens e híbridos de melão amarelo. Foi conduzido um ensaio em blocos casualizados com três repetições para avaliar 24 híbridos gerados pelos cruzamentos entre três linhagens elites utilizadas como genitores femininos (AF-01, AF-02 e AF-03), e oito linhagens utilizadas como genitores masculinos (LAM-01; LAM-02; LAM-03; LAM-04; LAM-05; LAM-06; LAM-07 e LAM-08). Foram avaliados caracteres a produção e a qualidade do fruto. Realizou-se a análise dialélica parcial para estimação das capacidades geral e especifica de combinação. Observou-se efeitos aditivos e não aditivos para os caracteres produtividade, peso médio do fruto e espessura da polpa. As linhagens AF-02, LAM-02 e LAM03 são as mais promissoras por possuir maior frequência de alelos favoráveis. Os híbridos de maior destaque foram AF-02 x LAM-02, AF-02 x LAM-03, AF-02 x LAM-04 e AF-03 $x$ LAM-06.

Palavras-chave: Cucumis melo L., capacidade de combinação, heterose, dialelo.

\section{INTRODUCTION}

Melon (Cucumis melo L.) is the most economically important cucurbits in the semi-arid Northeast of Brazil. The main production areas are the Mossoró-Açu agricultural region in Rio Grande do Norte, and in the Jaguaribe Valley, Ceará, These states account for more than $85 \%$ of Brazilian production, and nearly all ( $>99 \%)$ of the melon exported from Brazil comes from these states (SIDRA/IBGE, 2019). The crop also has a significant social impact because it utilizes a large number of laborers throughout the year, it is estimated that the melon production chain directly and indirectly involves more than 60,000 jobs (NUNES et al., 2016).
Growing melon in the semi-arid region of Brazil has been successful mainly because of environmental conditions, such as low annual rainfall $\left(<600 \mathrm{~mm}\right.$ year $\left.{ }^{-1}\right)$, high mean temperatures $\left(>30{ }^{\circ} \mathrm{C}\right)$, and intense sunlight $(2500-3000$ hours of sunlight year $\left.{ }^{-1}\right)$. In addition, the crop is developed by a production sector that uses high technology with modern techniques of irrigation, many inputs, and a sophisticated post-harvest structure for export of quality fruit to the European market. One of the most important inputs is seed from breeding programs, especially single hybrid seed (NUNES et al. 2016).

Hybrid seeds for growing cucurbits were introduced throughout the world in the mid-1970s (GUSMINI \& WEHNER, 2008). In Rio Grande 
do Norte and Ceará, this began in the 1980s. The cultivars grown in the production areas are nearly all single hybrids. Exceptions are the open pollination varieties of melon, like Honey Dew (NUNES et al. 2011a). Big advantages of the use of single hybrids are high yield $\left(>25 \mathrm{tha}^{-1}\right)$, higher quality $\left(>11^{\circ}\right.$ Brix $)$, and, above all, product uniformity, one of the main requirements of the foreign market.

The demand for hybrid seeds from producers has caused plant-breeding programs throughout the world to expend effort in obtaining increasingly high yielding hybrids that are also resistant to the main pathogens of the crop. The first step in producing hybrid melon seeds is obtaining lines with high performance themselves, with a high concentration of favorable alleles. In addition to the intrinsic performance of a line, it is important to estimate its combining ability, aiming to utilize heterosis since the main traits of economic importance, such as soluble solids content and yield, are controlled by additive and non-additive (dominance) effects (BARROS et al. 2011; FEYZIAN et al. 2009; POUYESH et al. 2017; ZALAPA et al.2006). The main breeding programs use the elite lines of companies to study the combining ability of the most promising lines, generally obtained by the pedigree method.

Diallel crosses are one of the techniques most used by breeders to study the combining ability of lines. From the diallel analysis method proposed by GRIFFING (1956), one of the methods most used, estimates can be obtained of general and specific combining ability, information on genetic control of the traits, and an estimation of heterosis. Consequently, diallel analysis allows the breeder to identify the best hybrid combinations, both for immediate utilization in the form of $\mathrm{F}_{1}$ hybrids and for the choice of segregating populations for obtaining lines with greater potential for generating superior hybrids. In melon, the diallel cross technique has been successfully used by various authors to choose parents and/or to study the inheritance of relevant traits (BARROS et al. 2011; FEYZIAN et al. 2009; KALB \& DAVIS 1984; LIPPERT \& LEGG 1972; MOHAMMADI et al. 2014; POUYESH et al. 2017).

Within the context mentioned above, the aim of the present study was to evaluate the agronomic potential of yellow melon lines and hybrids.

\section{MATERIALS AND METHODS}

Site

The study was conducted in Baraúna, RN $\left(5^{\circ} \mathrm{S}, 37^{\circ} \mathrm{W}\right.$ and $\left.109 \mathrm{MASL}\right)$. According to the Köppen classification, the climate is BSwh' (CARMO FILHO et al., 1991). Soil at the location was classified as an Argissolos Vermelhos and corresponds to Ultisoil in the Soil Taxonomy (EMBRAPA, 2018). Soil chemical analysis exhibited the following characteristics: $\mathrm{pH}=$ $6.40, \mathrm{Ca}=8.50 \mathrm{meq} / 100 \mathrm{ml}, \mathrm{Mg}=2.90 \mathrm{meq} / 100 \mathrm{ml}$, $\mathrm{Al}=0.10 \mathrm{meq} / 100 \mathrm{ml}, \mathrm{H}+\mathrm{Al}=120 \mathrm{meq} / 100 \mathrm{ml}, \mathrm{K}$ $=0.79 \mathrm{meq} / 100 \mathrm{ml}, \mathrm{P}=13.90 \mathrm{ppm}, \mathrm{Na}=19.00 \mathrm{ppm}$, and O.M. $=1.20 \mathrm{ppm}$.

\section{Germplasm}

The lines AF-01, AF-02, and AF-03 were used as female parents and LAM-01, LAM-02, LAM-03, LAM-04, LAM-05, LAM-06, LAM-07, and LAM-08 as male parents. All are yellow melon group inodorus Naud. (Cucumis melo L.) developed by the pedigree method. The lines were manually crossed in a 3:1 proportion, i.e., one maternal line for three paternal lines, and pollination was performed by touching the stamens of the pollen donor flower on the stigma of the receiver flower.

\section{Experimental design}

The eleven parent lines described and 24 hybrids obtained from them were evaluated in a partial diallel scheme under open field conditions. A randomized complete block experimental design was used with 35 treatments ( 11 parents +24 experimental hybrids) and three replications. A plot consisted of seven plants at a spacing of $2.0 \times 0.40 \mathrm{~m}$. A second experiment was carried out in completely randomized blocks with three replications to compare the hybrids that stood out in the diallel evaluation with five yellow melon hybrids cultivated by private farmers (4945, Goldex, Soleares, Iracema and Gladial). The plot size and cultural practices were the same applied in the first experiment.

\section{Traits}

The traits evaluated were: yield, in $\mathrm{t} \mathrm{ha}^{-1}$; mean fruit weight, in grams $(\mathrm{g})$; number of marketable fruits per plant; pulp thickness, in millimeters $(\mathrm{mm})$; total soluble solids, in ${ }^{\circ} \mathrm{Brix}$; and pulp firmness. This last measurement of pulp resistance was made using a Wagner ${ }^{\circledR}$ penetrometer with an $8.0 \mathrm{~mm}$ conical tip plunger (Fruit Pressure Tester - FT 011 Model), and results were expressed in kgf (NUNES et al. 2011a).

\section{Statistical analysis}

The data obtained were subjected to univariate analysis of variance, considering fixed treatment effects and to the Snedecor $\mathrm{F}$ test at 5\% probability. The mean values (of the three replications) 
of the parents and of the F1s were analyzed according to the partial diallel model proposed by GERALDI \& MIRANDA FILHO (1988), which is an adaptation of the model proposed by GRIFFING (1956). All the analyses were processed by the genetics and statistics computational application GENES (CRUZ, 2013).

\section{RESULTS AND DISCUSSION}

A significant effect $(\mathrm{P}<0.01)$ of treatments was observed for all the traits evaluated (Table 1). Regarding general combining ability (GCA), in the two groups of parents, and specific combining ability (SCA), a significant effect $(\mathrm{P}<0.01)$ was reported for yield, mean fruit weight, and pulp thickness $(\mathrm{P}<0.01)$. In a diallel analysis, the significance of the GCA and SCA indicated the presence of additive and non-additive (dominance) effects involved in genetic control of the trait.

The GCA (additive) and SCA (nonadditive) depend on the allele frequency of the parents involved in the diallel and on the level of dominance of the trait. The general combining ability effect is an indicator of the superiority of the population, in terms of frequency of the favorable genes, and of the differences between the gene frequencies of the population and the mean frequencies in the group (VIANA, 2007). This; therefore, demonstrated that results that differ among studies mainly arise from the group of parents used in the experiments. In addition, the effect of the environment and the method of analysis likewise influence the estimates and results achieved.
Concerning yield, diallel analysis studies reported additive and non-additive effects (FEYZIAN et al., 2009; MOHAMMADI et al., 2014; POUYESH et al. 2017; SHASHIKUMAR \& PITCHAIMUTHU, 2016). For mean fruit weight, the results of the present study were corroborated by BARROS et al. (2011), FEYZIAN et al. (2009), KALB \& DAVIS (1984), LIPPERT \& LEGG (1972), POUYESH et al. (2017), SINGH \& RANDHAWA (1990), and SHASHIKUMAR \& PITCHAIMUTHU (2016), who reported additive and non-additive effects. For pulp thickness, BARROS et al. (2011) and POUYESH et al. (2017) observed the same results as in the present study, namely, significant additive and non-additive effects. Nevertheless, in studies carried out by KALB \& DAVIS(1984),KITROONGRUANGPOO-SWANG \& TOKUMASU (1992), and SINGH\& RANDHAWA (1990), significant additive and non-additive effects were not detected for pulp thickness. Discordant results can be explained by the parents involved.

For the traits of number of fruits per plant, pulp firmness, and soluble solids, significant effects were not detected by the Snedecor F test in any of the sources of variation ( $p>0.05$ ) (Table 1). KITROONGRUANG POO-SWANG and TOKUMASU (1992) and SINGH and RANDHAWA (1990) reported that only additive effects were present in genetic control for number of fruits; therefore, contrasting from the results of the present study. The results obtained by BARROS et al. (2011) and SHASHIKUMAR and PITCHAIMUTHU (2016) also differed from those of the present study for number of fruits per plant and pulp firmness. These authors detected significance of the additive and nonadditive effects for these variables.

Table 1 - Summary of diallel analysis for six traits evaluated in a partial diallel involving two groups of yellow melon lines.

\begin{tabular}{|c|c|c|c|c|c|c|c|}
\hline \multirow[t]{2}{*}{ SV } & \multirow[t]{2}{*}{ df } & \multicolumn{6}{|c|}{--MS (Traits)--- } \\
\hline & & YIELD & MFW & NMF & PT & SS & $\mathrm{PF}$ \\
\hline (Treatments) & (34) & $185.95^{* *}$ & $0.39^{* *}$ & $0.67^{* *}$ & $28.58^{* *}$ & $1.75^{* *}$ & $0.47^{* *}$ \\
\hline GCA (Group I) & 2 & $1148.88^{* *}$ & $72.82^{* *}$ & $1.04^{\mathrm{ns}}$ & $39.99^{* *}$ & $0.74^{\mathrm{ns}}$ & $0.13^{\text {ns }}$ \\
\hline GCA (Group II) & 7 & $254.65^{* *}$ & $185.28^{* *}$ & $0.58^{\text {ns }}$ & $31.459^{* *}$ & $3.47^{\text {ns }}$ & $0.68^{\text {ns }}$ \\
\hline SCA (I x II) & 24 & $93.08^{* *}$ & $349.42^{* *}$ & $0.46^{\mathrm{ns}}$ & $13.23^{* *}$ & $1.401^{\mathrm{ns}}$ & $0.32^{\text {ns }}$ \\
\hline Groups & 1 & $8.10^{\mathrm{ns}}$ & $8937.83^{* *}$ & $5.52^{\mathrm{ns}}$ & $354.12^{* *}$ & $0.14^{\mathrm{ns}}$ & $3.36^{\mathrm{ns}}$ \\
\hline Error & 68 & 53.90 & 0.02 & 0.13 & 4.76 & 0.52 & 0.05 \\
\hline C.V. (\%) & & 23.49 & 8.32 & 28.32 & 4.70 & 5.74 & 8.13 \\
\hline Mean & & 30.92 & 1.70 & 1.28 & 46.41 & 12. & 2.83 \\
\hline
\end{tabular}

${ }^{* *},{ }^{*}$ : Significant by the Snedecor F test $(\mathrm{P}<0.01),{ }^{\text {ns }}$ : not significant. YIELD: yield in $\mathrm{t} \mathrm{ha}^{-1}$; MFW: mean fruit weight, in $\mathrm{g}$; NMF: number of marketable fruits per plant; PT: pulp thickness in the equatorial region of the fruit, in $\mathrm{cm}$; SS: total soluble solids, in ${ }^{\circ} \mathrm{Brix}$; PF: pulp firmness, in kgf. 
There are controversies in relation to genetic control for soluble solids: Barros et al. (2011), Kalb and Davis (1984), Shashikumar and Pitchaimuthu (2016), and Singh and Randhawa (1990) reported additive and non-additive effects, whereas Lippert and Legg (1972) detected only the additive effect as significant.

The estimates of GCA of the parent lines of the two groups involved in the partial diallel are shown in table 2. For yield, in the first group, the AF02 line stood out, whereas the lines LAM-02, LAM03, and LAM-06 stood out in the second group.

For mean fruit weight, lines AF-02 and AF-03, belonging to the first group, showed the highest estimates of GCA. In the second group, the lines LAM-03, LAM-02, and LAM-08 had the highest magnitudes for GCA.

Lines AF-02 and AF-01 had the highest estimates of GCA for pulp thickness in the first group, whereas line AF-03 had a negative estimate. In the second group, in decreasing order, lines LAM07, LAM-01, LAM-03, and LAM-02 had positive estimates, whereas lines LAM-08, LAM-04, LAM05, and LAM-06 had negative estimates (Table 2).

The GCA indicates the frequency of favorable alleles present in parents according to the trait. When the item of interest is the highest mean value for the trait, high and positive values of GCA indicate greater frequency of favorable alleles.
However, when the lowest mean value of the trait is beneficial for the genotype, high and negative values also indicated the greater frequency of favorable alleles. Thus, considering that in yellow melon, greater yield, fruit with thick pulp, and medium to large size (1600 to $2300 \mathrm{~g}$ ) are desirable traits, line AF-02 in the first group and LAM-02 and LAM-03 in the second group have a greater concentration of favorable alleles for these traits (Table 2). These lines contributed to obtain segregating populations with higher mean values in derived lines (FERREIRA et al., 2004).

In table 3 are the estimates of SCA and heterosis of the traits in which a significant effect of SCA was detected in diallel analysis. The magnitude of SCA indicated the degree of complementation of the parents of a cross. Its significance shows heterogeneous performance among the parents; consequently, it is not possible to predict their behavior based only on the GCA because interactions occur among the parents as a result of divergence in the loci with dominance.

For yield, the combinations that stood out, in decreasing order, were AF-03 x LAM-06, AF-02 $\mathrm{x}$ LAM-04, AF-02 x LAM-02, and AF-02 x LAM-03. For mean fruit weight, the crosses with the highest estimates for SCA, in decreasing order, were AF-02 x LAM-03, AF-02 x LAM-02, AF-02 x LAM-04, and AF-03 x LAM-06. The line AF-02 was among the highest estimates of SCA for both traits (Table 3 ).

Table 2 - Estimates of general combining ability (GCA) for yield, mean fruit weight, and pulp thickness in a partial diallel with two groups of yellow melon lines.

\begin{tabular}{|c|c|c|c|}
\hline \multirow[t]{2}{*}{ Parent } & ------- & A (Tra & --.-- \\
\hline & YIELD & MFW & PT \\
\hline AF-01 & -4.19 & -1.64 & 0.61 \\
\hline AF-02 & 6.43 & 0.89 & 0.61 \\
\hline AF-03 & -2.27 & 0.75 & -1.22 \\
\hline $\mathrm{DP}\left(\mathrm{g}_{\mathrm{i}}\right)$ & 0.99 & 0.19 & 0.29 \\
\hline LAM-01 & -0.30 & 0.46 & 1.13 \\
\hline LAM-02 & 4.12 & 2.08 & 0.51 \\
\hline LAM-03 & 2.59 & 4.99 & 1.11 \\
\hline LAM-04 & -3.86 & -0.73 & -1.46 \\
\hline LAM-05 & -1.07 & -4.35 & -0.36 \\
\hline LAM-06 & 3.93 & -0.61 & -0.26 \\
\hline LAM-07 & 0.04 & -3.24 & 1.26 \\
\hline LAM-08 & -5.45 & 1.39 & -1.94 \\
\hline $\operatorname{SD}\left(g_{i}\right)$ & 1.49 & 0.29 & 0.44 \\
\hline
\end{tabular}

YIELD: yield, in $\mathrm{t} \mathrm{ha}^{-1}$; MFW: mean fruit weight, in g; PT: pulp thickness in the equatorial region of the fruit, in $\mathrm{cm}$. SD: standard deviation. 
Table 3 - Estimate of specific combining ability (SCA) and heterosis of yield, mean fruit weight, and pulp thickness in a partial diallel with two groups of yellow melon lines.

\begin{tabular}{|c|c|c|c|c|c|c|c|}
\hline \multirow[t]{2}{*}{ Cross } & \multicolumn{4}{|c|}{ 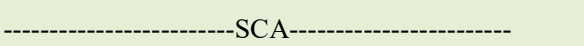 } & \multicolumn{3}{|c|}{ 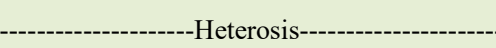 } \\
\hline & YIELD & MFW & PT & & YIELD & MFW & PT \\
\hline AF-01 x LAM-01 & 1.40 & -7.518 & -0.104 & & 0.04 & -8.98 & -2.82 \\
\hline AF-01 x LAM-02 & -4.06 & -0.805 & -1.685 & & -5.11 & -3.11 & -5.42 \\
\hline AF-01 x LAM-03 & 1.84 & -5.520 & -1.086 & & 1.67 & -6.07 & -4.01 \\
\hline AF-01 x LAM-04 & -0.33 & -4.255 & 0.685 & & -1.84 & -5.98 & -0.50 \\
\hline AF-01 x LAM-05 & -2.54 & -5.775 & -1.478 & & -4.12 & -6.83 & -5.17 \\
\hline AF-01 x LAM-06 & -2.23 & 1.818 & 1.286 & & -1.51 & -0.79 & 1.49 \\
\hline AF-01 x LAM-07 & -1.23 & -5.613 & -0.377 & & -4.26 & -7.27 & -2.51 \\
\hline AF-01 x LAM-08 & 1.44 & -4.118 & -2.368 & & -1.97 & -7.30 & -8.70 \\
\hline AF-02 x LAM-01 & -0.43 & 5.016 & -1.979 & & 2.32 & 13.40 & 1.09 \\
\hline AF-02 x LAM-02 & 5.65 & 11.999 & 2.038 & & 8.72 & 20.65 & 10.88 \\
\hline AF-02 x LAM-03 & 4.60 & 16.814 & 2.837 & & 8.55 & 22.59 & 12.66 \\
\hline AF-02 x LAM-04 & 10.60 & 10.939 & 3.678 & & 13.21 & 19.06 & 15.29 \\
\hline AF-02 x LAM-05 & -0.25 & 7.089 & 1.786 & & 2.29 & 17.19 & 10.41 \\
\hline AF-02 x LAM-06 & -4.27 & 7.883 & 0.210 & & 0.57 & 19.60 & 7.80 \\
\hline AF-02 x LAM-07 & -3.83 & 4.922 & 0.687 & & -2.74 & 14.85 & 7.93 \\
\hline AF-02 x LAM-08 & -1.32 & 5.546 & 0.696 & & -0.61 & 13.37 & 6.43 \\
\hline AF-03 x LAM-01 & -0.73 & -1.633 & 2.048 & & -1.91 & -0.53 & 6.46 \\
\hline AF-03 x LAM-02 & -0.06 & 1.279 & 0.997 & & -0.92 & 3.53 & 5.01 \\
\hline AF-03 x LAM-03 & -1.42 & -2.365 & -0.134 & & -1.41 & 0.90 & 2.59 \\
\hline AF-03 x LAM-04 & -10.59 & -0.911 & -2.892 & & -11.91 & 1.31 & -3.84 \\
\hline AF-03 x LAM-05 & 2.20 & 5.439 & 0.874 & & 0.82 & 5.25 & 4.73 \\
\hline AF-03 x LAM-06 & 15.06 & 9.233 & 1.308 & & 15.97 & 9.26 & 6.70 \\
\hline AF-03 x LAM-07 & -1.35 & 3.072 & 1.385 & & -4.19 & 3.16 & 5.99 \\
\hline AF-03 x LAM-08 & -8.05 & -7.163 & -0.006 & & -11.27 & -3.86 & 1.10 \\
\hline $\mathrm{SD}\left(\mathrm{s}_{\mathrm{ii}}\right)$ & 3.34 & 0.644 & 0.991 & $\mathrm{r}$ & $0.93^{* *}$ & $0.94^{* *}$ & $0.88^{* *}$ \\
\hline $\mathrm{SD}\left(\mathrm{s}_{\mathrm{jj}}\right)$ & 2.68 & 0.516 & 0.795 & & & & \\
\hline $\mathrm{SD}\left(\mathrm{s}_{\mathrm{ij}}\right)$ & 3.76 & 0.725 & 1.116 & & & & \\
\hline
\end{tabular}

${ }^{* *}$ Significant by the Mantel test $(\mathrm{p}<0.01)$. YIELD: yield, in $\mathrm{t} \mathrm{ha}^{-1}$; MFW: mean fruit weight, in g; PT: pulp thickness in the equatorial region of the fruit, in $\mathrm{cm}$. SD: standard deviation.

The highest estimates of SCA for pulp thickness were reported in the crosses AF-02 x LAM04, AF-02 x LAM-03, AF-03 x LAM-01, and AF-02 $x$ LAM-02 (Table 3). The lines AF-02 and AF-03 were present in four of the ten highest estimates.

Concerning heterosis, in terms of yield, the highest estimates were observed in the crosses AF03 x LAM-06, AF-02 x LAM-04, AF-02 x LAM-02, and AF-02 x LAM-03 (Table 3). In regard to mean fruit weight, the highest estimates of heterosis were observed in the crosses AF-02 x LAM-03, AF-02 x LAM-02, AF-02 x LAM-01, AF-02 x LAM-04, and AF-02 x LAM-05. The line AF-02 was involved in the eight highest estimates of heterosis. Regarding pulp thickness, the cross with greatest heterosis were AF-02 x LAM-04, AF-02 x LAM-03, AF-02 x LAM-
02, and AF-02 x LAM-05. The line AF-02 was in the six highest estimates of heterosis.

Positive heterosis indicated that the hybrid combination is better than the mean of the parents. However, the magnitude and the sign (positive or negative) of heterosis depend on the parents and on the trait that is being studied. Monforte et al. (2005) crossed a 'Pele de Sapo' melon line with thirteen accessions and found positive, negative, or null heteroses for mean fruit weight. Barros et al. (2011) reported results for mean fruit weight and pulp thickness similar to those of the present study. These authors used parents belonging to different botanical groups. In this study the obtained hybrids belong to the group inodorus Naud. just like your parents lines. 
According to Cruz \& Vencovsky (1989), when breeders choose parents or hybrids in diallel crosses, they should select the cross with high SCA, and at least one of the parents should have a high estimate of GCA. The idea was to join wide variability (genetic divergence and heterosis) and high frequency of favorable alleles (LYNCH \& WALSH, 1998). These characteristics make it possible to obtain high performance lines. In addition, the mean of the cross and of the parents themselves are important for choosing the best hybrid combination. Thus, the crosses that fulfill the conditions suggested by Cruz \& Vencovsky (1989) are mainly those that involve the elite line AF-02 as parent, especially the crosses AF$02 \times$ LAM-02, AF-02 x LAM-03, and AF-02 x LAM04, as well as the cross AF-03 x LAM-06 (Table 3). The lines with the highest frequency of favorable alleles (highest GCA) in their respective groups were AF-02, LAM-2, and LAM-03 (Table 2).

The hybrids that most stand out in the diallel (AF-02 x LAM-02, AF-02 x LAM-03, and AF-02 x LAM-04 plus AF-03 x LAM-06) exhibited performance similar to the main hybrids grown and were exported by the productive sector when compared in a trial under field conditions (Table 4).

An ideal yellow melon hybrid should have high yield $\left(>25 \mathrm{t} \mathrm{ha}^{-1}\right)$, fruit size acceptable to the foreign market (1.5 to $2.6 \mathrm{~kg}$ ), good pulp thickness $(>4.5 \mathrm{~cm})$, high pulp firmness $(>3.0 \mathrm{kgf})$, and high soluble solids content $\left(12.0^{\circ} \mathrm{Brix}\right)$ (NUNES et al. 2016b). All the hybrids that stood out in the diallel gathered together these characteristics since they have mean yields above the mean in the Northeast region; the number of fruits per plant was within the standard acceptable to the export market $(>1.5$ fruits/ plant); they have sufficient pulp firmness to bear up under sea transport and arrive in good condition for sale in European supermarkets; and they have soluble solids above the minimum required for yellow melon (ALVES et al. 2000).

Furthermore, these hybrids have excellent appearance regarding peel and pulp color and elliptical fruit shape, as desired for yellow melon (Figure 1). For these reasons, they are promising for use in melon cultivation under the conditions of the Brazilian semi-arid region. These hybrids will be evaluated under different growing conditions in coming years to confirm the results of the present study.

\section{CONCLUSION}

The lines AF-02, LAM-02, and LAM-03 are most promising for use as parents since they have higher frequency of favorable alleles. The hybrids that most stood out in diallel analysis were AF-02 $x$ LAM-02, AF-02 x LAM-03, AF-02 x LAM-04, and AF- $03 \times$ LAM-06, and they are promising for use in melon cultivation under the conditions of the Brazilian semi-arid region.

Table 4 - Mean of five traits evaluated in experimental and commercial hybrids of yellow melon.

\begin{tabular}{|c|c|c|c|c|c|c|}
\hline \multirow[t]{2}{*}{ Genotype } & \multicolumn{6}{|c|}{ 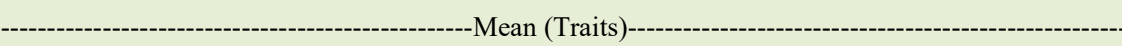 } \\
\hline & YIELD & MFW & $\mathrm{NMF}$ & PT & PF & SS \\
\hline \multicolumn{7}{|c|}{ 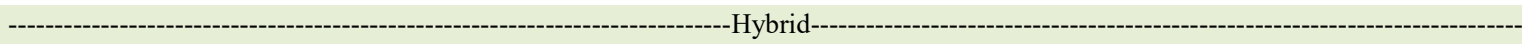 } \\
\hline AF-02 x LAM-02 & 42.78 & $2.07 \mathrm{c}$ & $1.65 \mathrm{a}$ & $4.96 \mathrm{a}$ & $2.39 \mathrm{~b}$ & $12.39 \mathrm{~b}$ \\
\hline AF-02 x LAM-03 & 36.68 & $2.28 \mathrm{~b}$ & $1.29 \mathrm{~b}$ & $5.10 \mathrm{a}$ & $2.78 \mathrm{~b}$ & $12.91 \mathrm{~b}$ \\
\hline AF-02 x LAM-04 & 33.26 & $1.75 \mathrm{~d}$ & $1.52 \mathrm{a}$ & $4.93 a$ & $3.68 \mathrm{a}$ & $12.32 \mathrm{~b}$ \\
\hline AF-03 x LAM-06 & 57.30 & $1.65 \mathrm{~d}$ & $1.31 \mathrm{~b}$ & $4.63 b$ & $2.53 b$ & $13.90 \mathrm{a}$ \\
\hline \multicolumn{7}{|c|}{ 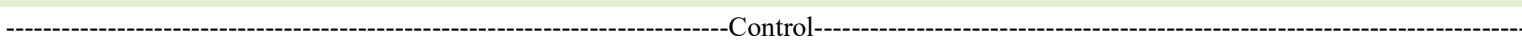 } \\
\hline 4945 & 36.54 & $1.98 \mathrm{c}$ & $1.48 \mathrm{a}$ & $4.85 \mathrm{a}$ & $2.45 \mathrm{~b}$ & $12.68 \mathrm{~b}$ \\
\hline Goldex & 28.07 & $1.89 \mathrm{c}$ & $1.19 \mathrm{~b}$ & $5.13 \mathrm{a}$ & $2.57 b$ & $13.75 \mathrm{a}$ \\
\hline Soleares & 30.61 & $1.69 \mathrm{~d}$ & $1.45 \mathrm{a}$ & $4.46 \mathrm{a}$ & $2.43 b$ & $13.35 \mathrm{a}$ \\
\hline Iracema & 37.44 & $2.39 \mathrm{~b}$ & $1.25 \mathrm{~b}$ & $5.15 \mathrm{a}$ & $2.16 \mathrm{~b}$ & $11.79 \mathrm{~b}$ \\
\hline Gladial & 43.34 & $2.60 \mathrm{a}$ & $1.33 b$ & $5.31 \mathrm{a}$ & $2.41 \mathrm{~b}$ & $13.26 \mathrm{a}$ \\
\hline
\end{tabular}

Mean values followed by the same lowercase letter belong to the same group according to Scott-Knott (1974). YIELD: yield, in t ha ${ }^{-1}$; MFW: mean fruit weight, in g; NMF: number of marketable fruits per plant; PT: pulp thickness in the equatorial region of the fruit, in cm; SS: total soluble solids, in ${ }^{\circ}$ Brix; PF: pulp firmness, in kgf. 

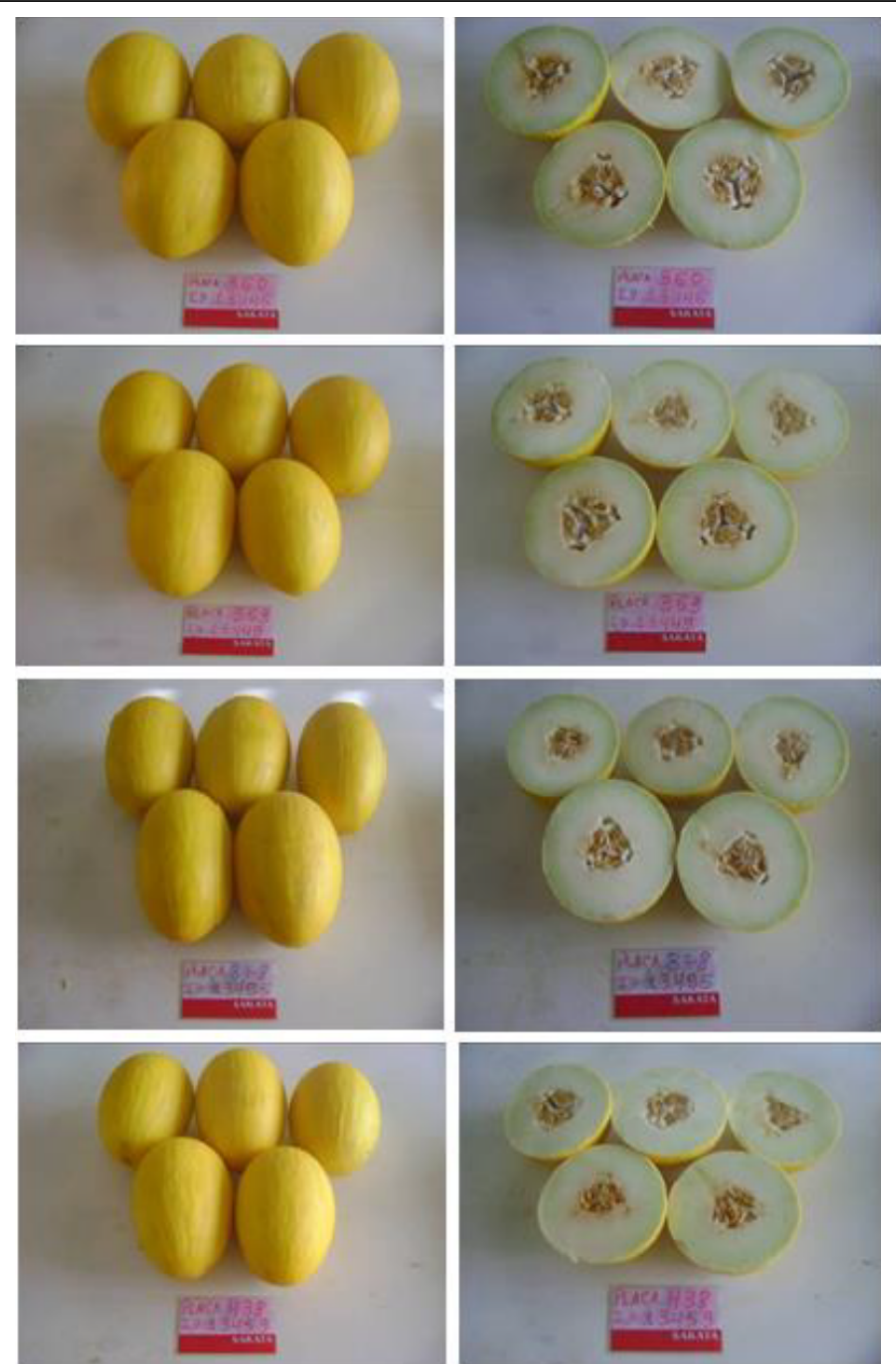

Figure 1 - Hybrids of the yellow melon group Inodorus obtained by crossings: AF-02 x LAM-02 (A), AF-02 x LAM-03 (B), AF-02 x LAM-03 (C), and AF-03 x LAM-06 (D) closed and open respectively.

\section{ACKNOWLEDGEMENT}

This study was financed in part by the CAPES, that granted students graduate scholarships, and by $\mathrm{CNPq}$, through of the research scholarships to Glauber Henrique de Sousa Nunes (309882/2017-6) and to Fernando Antonio Souza de Aragão (Process 312139/2017-9).

\section{DECLARATION OF CONFLICT OF INTERESTS}

The authors declare no conflict of interest. The founding sponsors had no role in the design of the study; in the collection, analyses, or interpretation of data; in the writing of the manuscript, and in the decision to publish the results.

\section{AUTHORS' CONTRIBUTIONS}

All authors contributed equally for the conception and writing of the manuscript. All authors critically revised the manuscript and approved of the final version.

\section{REFERENCES}

ALVES, R.E. et al. Manual de melão para exportação. Brasília: EMBRAPA, 2000. 51p.

BARROS, A.K.A. et al. Diallel analysis of yield and quality traits of melon fruits. Crop Breeding and Applied Biotechnology, v.11, p.313-319, 2011. Available from: <http://www.scielo.br/ scielo.php?script $=$ sci arttext\&pid $=$ S1984-70332011000400004 $>$. Accessed: Jan. 07, 2019. doi: 10.1590/S1984-70332011000400004.

Ciência Rural, v.50, n.2, 2020. 
CARMO FILHO, F. et al. Dados climatológicos de Mossoró: Um município semi-árido nordestino. Coleção Mossoroense 30. C. Mossoró: ESAM, 1991. 121p.

CRUZ, C.D. GENES - a software package for analysis in experimental statistics and quantitative genetics. Acta Scientiarum Agronomy, v.35, p.271-276, 2013.

CRUZ, C.D.; VENCOSKY, R. Comparação de alguns métodos de análise dialélica. Revista Brasileira de Genética, v. 12, p.425438, 1989.

EMBRAPA. Sistema brasileiro de classificação de solos. Brasília: Embrapa, ed 5, p.342-343, 2018. Available from: <https:// www.embrapa.br/solos/sibcs/correlacao-com-wrb-fao-e-soiltaxonomy>. Accessed: Oct. 03, 2019.

FERREIRA, F.M. et al. Genetic components of combining ability in a complete diallel. Crop Breeding and Applied Biotechnology, v.4, p.338-343, 2004. Available from: <https://www.researchgate. net/publication/269899560_Genetic_components_of_combining ability_in_a_complete_diallel $>$. Accessed: Jan. 07, 2019. doi: 10.12702/1984-7033.v04n03a12.

FEYZIAN, E. et al. Diallel cross analysis for maturity and yieldrelated traits in melon (Cucumis melo L.). Euphytica, v.168, p.215-223, 2009. Available from: <https://www.researchgate.net/ publication/259356208_Diallel_cross_analysis_for_maturity and yield-related_traits_in_melon_Cucumis_melo_L $>$. Accessed: Jan. 07, 2019. doi: $10.1007 / \mathrm{s} 10681-009-9904-9$.

GERALDI, I.O.; MIRANDA-FILHO, J.B. Adapted models for the analysis of combining ability of varieties in partial diallel crosses. Brazilian Journal of Genetics, Ribeirao Preto, v.11, p.419-430, 1988. Available from: <https://www.researchgate. net/ public ation/313083971_Adapted_models_for_the_analysis of_combining_ability_of_varieties_in_partial_diallel_crosses $>$. Accessed: Sep. 25,2019.

GRIFFING, B. A. Concept of general and specify combining ability in relation to diallel crossing systems. Australian Journal Biology Science, v.9, p.463-493, 1956. Available from: <https:// www.publish.csiro.au/bi/pdf/BI9560463>. Accessed: Jan. 07, 2019.

GUSMINI, G.; WEHNER, T.C. Fifty-five years of yield improvement for cucumber, melon, and watermelon in the United States. HortTechnology, v.18, p.9-12, 2008. Available from: $<$ https://www.researchgate.net/publication/251739919_Fiftyfive Years of Yield Improvement for Cucumber Melon and Watermelon_in_the_United_States>. Accessed: Jan. 07, 2019. doi: 10.21273/HORTTECH.18.1.9.

IBGE - Instituto Brasileiro de Geografia e Estatística. Available from: $<$ https://sidra.ibge.gov.br/pesquisa/censo-agropecuario/censoagropecuario-2017> Accessed: Oct. 03, 2019.

KALB, T.J.; DAVIS, D.W. Evaluations of combining ability, heterosis and genetic variance for fruit quality characteristics in bush muskmelon. Journal American Society Horticulture Science, Alexandria, v. 109, p.411-415, 1984.

KITROONGRUANG, N. et al. Evaluation of combining ability, heterosis and genetic variance for plant growth and fruit quality characteristics in Thain-melon (Cucumis melo L.). Science Horticulture, v.50, p.79-87, 1992. Available from: <https://
www.researchgate.net/publication/248477207_Evaluation_of_ combining ability heterosis and genetic variance for plant growth_and_fruit_quality_characteristics_in_Thai-melon_Cucumis melo L var acidulus Naud>. Accessed: Jan. 07, 2019. doi: $10.1016 / \mathrm{S} 0304-4238(05) 80011-1$.

LIPPERT, F.L.; LEGG, P.D. Diallel analysis for yield and maturity characteristics in muskmelon cultivars. Journal American Society Horticulture Science, v. 97, p.87-90, 1972.

LYNCH, M.C.; WALSH, B. Genetics and analysis of quantitative descriptors. Sunderland: Sinauer Associates Inc., 1998. 980p.

MOHAMMADI, R. et al. Genetic analysis of yield components, early maturity and total soluble solids in cantaloupe (Cucumis melo L. subsp. melo var cantalupensis Naudin). YYU J. Scientia Agricola, v.24, p.79-86, 2014. Available from: <http://dergipark. gov.tr/download/article-file/204666>. Accessed: Jan. 07, 2019.

MONFORTE, A.J. et al. Inheritance mode of fruit traits in melonheterosis for fruit shape and its correlation with genetic distance. Euphytica, v.144, p.31-38, 2005. Available from: $<$ https://ink.springer.com/article/10.1007/s10681-005-0201-y>. Accessed: Jan. 07, 2019.

NUNES G.H.S. et al. Divergência genética entre linhagens de melão do grupo Inodorus. Revista Ciência Agronômica, v.42, p.448-456, 2011(a). Available from: <http://ccarevista.ufc.br/seer/ index.php/ccarevista/article/view/960>. Accessed: Jan. 07, 2019.

NUNES G.H.S. et al. Melhoramento de Melão. In: Nick C.; Borém A. Melhoramento de Hortaliças. 1. ed. Viçosa, MG: Editora UFV, 2016. p. 331-363.

NUNES, G.H.S. et al. Influence of environmental variables on genotype by environment interaction in melon. Revista Brasileira de Fruticultura, v.33, n.4, p.1194-1199, 2011b. Available from: $<$ http://www.alice.cnptia.embrapa.br/alice/handle/doc/916830>. Accessed: Nov. 25, 2019.

POUYESH, A. et al. Genetic analysis of yield and fruit traits in cantaloupe cultivars. Plant Breeding, v.136, p.569577, 2017. Available from: <https://www.researchgate.net/ publication/318168163_Genetic_analysis_of_yield_and_fruit_ traits_in_cantaloupe_cultivars>. Accessed: Jan. 07, 2019. doi: $10.1111 /$ pbr. 12486 .

SHASHIKUMAR, K. T.; M. PITCHAIMUTHU. Heterosis and combining ability analysis of quantitative and qualitative traits in muskmelon (Cucumis melo L). International Journal of Agricultural Science, v.6, p.341-348, 2016. Available from: $<$ http://www.tjprc.org/publishpapers/2-50-1465548686-46.\%20 I J A S R \% 20 - \% $20 \% 20$ H E T E R O S I S \% 20 A N D \% 20 COMBINING\%20ABILITY\%20ANALYSIS\%200F\%20 QUANTITATIVE\%20AND.pdf>. Accessed: Jan. 07, 2019.

SINGH, M.J.; RANDHAWA, K.S. Assessment of heterosis and ability for traits in muskmelon. Indian Journal Horticulture, v.47, p.228-232, 1990.

TOMAR R.S.; BHALALA M.K. Combining ability studies in Muskmelon (Cucumis melo L.). Journal of Horticultural Science, v.1, p.109-115, 2006. Available from: <http://www.sphindia.org/ index.php/jhs/article/viewFile/362/360>. Accessed: Jan. 07, 2019. 
VIANA, J.M.S. Heterosis and Combining Ability Analyses from the partial diallel. Bragantia, v.66, p.641-647, 2007. Available from: $\quad<\mathrm{http}$ //www.scielo.br/scielo.php?script=sci_arttext\&pid =S0006-87052007000100007>. Accessed: Jan. 07, 2019. doi: 10.1590/S0006-87052007000100007.
ZALAPA, J. E. et al. Generation means analysis of plant architectural traits and fruit yield in melon. Plant Breeding, v.125, p.482-487, 2006. Available from: <https://onlinelibrary.wiley. com/doi/full/10.1111/j.1439-0523.2006.01273.x>. Accessed: Jan. 07, 2019. doi: 10.1111/j.1439-0523.2006.01273.x. 